\title{
Characterization of Environmental Samples around an Indigenous Refinery in Nigeria
}

\author{
Useh Mercy Uwem ${ }^{1,3 \text {, *, Useh Uwem Jonah², Dauda Mary Sunday }}{ }^{3}$ \\ ${ }^{1}$ Chemistry Advanced Research Centre, Sheda Science and Technology Complex, Abuja, Nigeria \\ ${ }^{2}$ Department of Pollution Control, Ecological Fund Office, Federal Secretariat Phase 2, Abuja, Nigeria \\ ${ }^{3}$ Department of Chemistry, University of Abuja, Abuja, Nigeria
}

\section{Email address:}

usehmercy@gmail.com (U. M. Uwem)

${ }^{*}$ Corresponding author

\section{To cite this article:}

Useh Mercy Uwem, Useh Uwem Jonah, Dauda Mary Sunday. Characterization of Environmental Samples around an Indigenous Refinery in Nigeria. Biochemistry and Molecular Biology. Vol. 2, No. 6, 2017, pp. 73-79. doi: 10.11648/j.bmb.20170206.12

Received: September 8, 2017; Accepted: October 8, 2017; Published: November 11, 2017

\begin{abstract}
Co-contamination by petrochemicals and heavy metals emanating from refinery operations was investigated from sludge, soil and water samples immediately around WRPC refinery, Delta State, Nigeria. Collection and assessment of environmental samples from 5 different points across the refinery and groundwater for which the $\mathrm{pH}$, Electrical Conductivity, Temperature, Turbidity, TDS, TSS, Total hardness, Alkalinity, DO, BOD, $\mathrm{Cl}^{-}, \mathrm{PO}_{4}{ }^{3-}$ and bacteriological analysis were measured. The total petroleum hydrocarbon and polycyclic aromatic hydrocarbon concentrations were 755.291 and $22.746 \mathrm{mg} \mathrm{L}^{-1}$ in the water samples, 8756.148 and $311.569 \mathrm{mg} \mathrm{kg}^{-1}$ for the soil samples, 65346.8 and 4190.598 $\mathrm{mg} \mathrm{kg}^{-1}$ for the sludge samples via GC-MS analysis. The effects of the release of the industrial effluents caused the increase in $\mathrm{pH}, 5.2-5.3$ across the studied samples. Conductivity measurements for the sludge, soil and water samples gave readings of $0.27,0.25$ and $0.48 \mu \mathrm{s} \mathrm{cm}^{-1}$ respectively. The presence and distribution of different heavy metals varied whereby the presence of cadmium $(0.139 \mathrm{mg} / \mathrm{l})$, cobalt $(0.34 \mathrm{mg} / \mathrm{l})$ and nickel $(0.606 \mathrm{mg} / \mathrm{l})$ in the water samples were above the WHO permissible limits. The highest concentrations of iron $(108.77 \mathrm{mg} / \mathrm{kg})$ and zinc $(11.072 \mathrm{mg} / \mathrm{kg})$ where observed in the soil samples while chromium $(24.25 \mathrm{mg} / \mathrm{kg})$, lead $(3.902 \mathrm{mg} / \mathrm{kg})$, mercury $(0.21 \mathrm{mg} / \mathrm{kg})$, arsenic $(0.417 \mathrm{mg} / \mathrm{kg})$, copper $(2.015$ $\mathrm{mg} / \mathrm{kg}$ ) and manganese $(82.695 \mathrm{mg} / \mathrm{kg})$ where highest in the sludge samples. Total bacterial enumeration revealed a count of $7.29 \times 10^{3}(\mathrm{cfu} / \mathrm{g}), 1.84 \times 10^{3}(\mathrm{cfu} / \mathrm{g})$ and $1.32 \times 10^{3}(\mathrm{cfu} / \mathrm{ml})$ in the soil, sludge and water samples respectively. The presence and concentrations of these mixed pollutants via the activities of the refinery resulted in change of known physicochemical properties which in turn affects the vegetative and microbial flora within the area.
\end{abstract}

Keywords: Total Petroleum Hydrocarbons, Polycyclic Aromatic Hydrocarbons, Heavy Metals, Physicochemical Properties

\section{Introduction}

The persistent use of petroleum and the increased demand for its by-products for numerous applications places a huge constraint on the immediate environment [1-2]. Operational activities around petroleum refineries like several in the Niger Delta region of Nigeria are renowned for its cumulative oil spills due to large oil deposits [3-5]. These sites are poorly and most often never investigated to know the extent of petroleum hydrocarbon contamination and as a result there is high possibility of accumulation of these pollutants in the food chain by their consumption in drinking water, fish and crops, which could pose a risk to human and other terrestrial and aquatic life [6-8]. Crude oil pollution from spills and poor waste disposal affect the physicochemical properties of soils with sometimes also the build-up of high concentrations of heavy metals in the affected sites [9]. Overall, the sources of livelihood in impacted areas which include farmlands, rivers and forests have been negatively affected [10].

Polycyclic aromatic hydrocarbons (PAH) and BTEX (benzene, toluene, ethylbenzene and xylene) represent uniquely hazardous components of petroleum hydrocarbons [11-13]. Exposure to such compounds for prolong periods 
can cause the distortions of soil texture, saturated hydraulic conductivity, porosity and compaction in addition to creating a generally unsuitable environment for the growth of biological life [14-15].

Co-contamination by inorganic compounds like heavy metals, radionuclides and other synthetic compounds, all constitute the main mix of environmental pollutants around petrochemical industrial areas [16]. Although heavy metals at extreme concentrations are toxic to microorganisms, plants, animals and humans, a substantial proportion of minerals (metals at acceptable concentrations) are beneficial [17]. Within the sludge, a number of factors influence heavy metal use in sludge, such as $\mathrm{pH}$, redox potential, the presence of other ions, organic matter content, sludge texture, microbial activity, etc. The toxicity of different forms of heavy metals depends on factors such as physical state, gas, solution, or powder particle size, cell adsorption rate, elimination rate, and the nature of chemical substituents in the toxic compound [18].

Quantification of the respective types and concentration of polluting agents creates a necessary baseline for the protection and remediation of the immediate environment around petrochemical industries. Studies show that preliminary tests geared towards the soil and water physical, chemical and biological characteristics underlines the success of remediation strategies that could be employed as well as serves as the basic indicators to monitor soil pollution [1920]. The aim of this study was to assess the effect of petroleum hydrocarbons on the physicochemical properties of sludge, soil and water from an indigenous oil refinery, Warri Refinery and Petrochemical Company (WRPC) Ltd.

\section{Materials and Methods}

\subsection{Sample Collection}

US EPA (SW-846) guidelines were applied, using simple random sampling for collecting oily sludge/sediment samples A total of fifteen (15) samples were used for the present analysis. Five (5) oily sludge samples were randomly collected with core sampler in a $500 \mathrm{~mL}$ wide-mouth glass jar from the project site area of Ubeji (an area bounding WRPC, and popularly referred to in this study as WRPC Phase 2 Clean-up project). Five (5) soil samples were randomly collected using soil auger from the oil-impacted environs and stored in sealed polythene bags. The subsamples were homogenized to get a composite sample of each and were properly labelled and transported to the laboratory for pretreatment and analyses. The soil samples were air-dried for two weeks, rolled manually, mixed and sieved with $2 \mathrm{~mm}$ mesh to remove stones and debris. Also, five (5) water samples were collected in the said area in well-labelled 1liter amber glass bottles with teflon-lined screw cap and were preserved at the time of collection with concentrated $\mathrm{HCl}$ to $\mathrm{pH}<2$ and held at $4^{\circ} \mathrm{C}$ immediately after collection until extracted within 14 days.

\subsection{Hydrocarbon Analysis}

The liquid-liquid extraction (LLE) technique as stated in the USEPA Method 3510 was employed in conjunction with Method 3500c for the water sample. 1 liter of the sample was serially extracted with $60 \mathrm{~mL}$ of methylene chloride at a $\mathrm{pH}$ greater than 11 (with sodium hydroxide solution) and again at a $\mathrm{pH}$ less than 2 (with sulfuric acid) using a separatory funnel with the intent of achieving good recovery of the desired analytes. $1.0 \mathrm{~mL}$ of the surrogate spiking solution was added and mixed. The technique required strong shaking with periodic venting to release excess pressure, followed by the separation of the organic layer (extract) from the aqueous phase. The extract was then filtered through a desiccant (anhydrous $\mathrm{Na}_{2} \mathrm{SO}_{4}$ ) to remove moisture and concentrated using Snyder column to a volume of $1 \mathrm{~mL}$ prior to the analysis. A test portion of $5.00 \mathrm{~g}$ of the soil sample was weighed into $20-\mathrm{mL}$ glass scintillation vials, and $10 \mathrm{~mL}$ of methylene chloride was added to each vial. The vials were sealed with a foil-lined cap and shaken on a reciprocating platform shaker (Eberbach 6010, Fisher Scientific, St. Louis, MO) at 120 cycles/min for $1 \mathrm{~h}$. The extracts were centrifuged for $10 \mathrm{~min}$ at $2000 \mathrm{rpm}$ and removed carefully from the centrifuge, and the extraction solution was decanted and stored at $4^{\circ} \mathrm{C}$ until analysis. For the oily sludge sample, soxhlet extraction (EPA Method SW-846 3540) was employed because it is quite efficient for the extraction of the semivolatiles. $20 \mathrm{~g}$ of sample was extracted using $500 \mathrm{ml}$ of methylene chloride for $24 \mathrm{~h}$. $10 \mathrm{~g}$ of anhydrous sodium sulphate was mixed with the sample immediately prior to extraction to remove water.

Replication of extraction ranged from $n=3$ to $n=5$. The extraction solutions were sealed in glass vials and stored at $4^{\circ} \mathrm{C}$ until analysis. All the samples were analysed by GC/MS using an Agilent 7890 Series GC (Agilent J\&W DB-UI 8270D) coupled with MS 6975 MSD single quadrupole system. Analysis of total petroleum hydrocarbons (TPH) and quantification of polyaromatic hydrocarbons (PAHs) in each sample was performed according to EPA method 8270D2007 [26-27].

\section{GC-MS Instrumentation and Conditions}

GC-MS analysis was performed on an Agilent 7890 Series GC (Agilent J\&W DB-UI 8270D) coupled with MS 6975 MSD and a $30 \mathrm{~m}, 0.32 \mathrm{~mm}$ ID $0.5 \mu \mathrm{m}$ film thickness fused silica capillary column. Helium was used as the carrier gas and the column head pressure was maintained at $10 \mathrm{psi}$ to give a flow rate of $1.0 \mathrm{ml} / \mathrm{min}$. The injector and transfer line were set at $270^{\circ} \mathrm{C}$ and $320^{\circ} \mathrm{C}$, respectively. The initial temperature was kept at $80^{\circ} \mathrm{C}$ for $1 \mathrm{~min}$, ramped to $200^{\circ} \mathrm{C}$ at a rate of $5^{\circ} \mathrm{C} / \mathrm{min}$, to $270^{\circ} \mathrm{C}$ at $3^{\circ} \mathrm{C} / \mathrm{min}$, and ramped to $320^{\circ} \mathrm{C}$ at $15^{\circ} \mathrm{C} / \mathrm{min}$ and held at that temperature for $10 \mathrm{~min}$. A $1 \mu \mathrm{g} i \mathrm{~L}$ aliquot was injected in the splitless mode with a 1-min purgeoff. The MS was scanned from 50 to 550 amu range at 0.8 scan/s by selecting full-scan mode. The quantification of TPH in a sample from the GC run was conducted through total chromatographic area counts based on internal standards (IS). HP MS-ChemStation (DOS series) was used to program 
the data acquisition and analysis.

\subsection{Determination of Soil Physicochemical Properties}

Percentage moisture content was determined using standard methods [21]. $1 \mathrm{~kg}$ each of soil and sludge samples were weighed out and heated overnight at $105^{\circ} \mathrm{C}$ in an oven. The samples were then allowed to cool for an hour in a desiccator prior to taking weight measurements. The percentage moisture content (\% MC) was calculated using the equation below;

$$
\% M C=\frac{[\text { Weight of wet soil }(\mathrm{g})-\text { Weight of dried soil }(\mathrm{g})] \times 100 \%}{\text { Weight of wet soil }(\mathrm{g})}
$$

Sludge, soil and water $\mathrm{pH}$ analysis was determined for all samples using a digital pH meter (Jenway model 3015) with a glass-calomel electrode combination with vigorous stirring [22]. Approximately $10 \mathrm{~g}$ each of soil and sludge samples were crushed, air-dried and sieved using a $2.0 \mathrm{~mm}$ mesh then weighed into a $100 \mathrm{ml}$ beaker to which $20 \mathrm{ml}$ distilled water was added (ratio 1:2 soil/sludge to water). The suspensions were stirred vigorously with a glass rod to form homogenous slurries then left to stand at room temperature for 20 minutes. $\mathrm{pH}$ was determined using a pre-calibrated Jenway $3015 \mathrm{pH}$ meter. Then the glass electrode of the $\mathrm{pH}$ meter was placed into the settled suspension in each beaker and the $\mathrm{pH}$ value of each sample beaker was recorded. Conductivity measurements were determined using a conductivity meter (Systronics-304) on a fresh soil, sludge and water samples at $25^{\circ} \mathrm{C}$. The total organic matter was quantified according to standard methods [21]. Total alkalinity, sulphates and chlorides were estimated using standard protocols [23]. The temperature of all three samples was determined in-situ using the mercury-in-glass thermometer. Total hardness by titrimetric method, total dissolved solids by gravimetric methods, total suspended solids by filtration method, dissolved oxygen by titrimetric method, dissolved oxygen and biological oxygen demand by APHA method [24].

\subsection{Estimation of Microbiological Population}

Enumeration of the total bacterial count was determined using the most probable number (MPN) method by which heterotrophic bacteria was estimated using colony counts on nutrient agar via the pour plate technique [25].

\subsection{Heavy Metals Analysis}

$5 \mathrm{~g}$ of each soil sample was digested using aqua regia digestion method (USEPA 3050). After filtration through a funnel lined with Whatman No. 42 filter paper, the filtrate was collected into a $100 \mathrm{ml}$ well-labeled polyethylene bottle prior to analysis. All digestions were carried out in triplicate for each sample and the amounts of trace metals recorded as mean value. $500 \mathrm{ml}$ of each water sample was evaporated to about $100 \mathrm{ml}$, then, $10 \mathrm{ml}$ of conc. $\mathrm{HNO}_{3}$ was added and the solution was placed on a heating mantle at low heat for 30 min. After cooling, it was filtered and made up to $100 \mathrm{ml}$ with deionized-distilled water. For the oily sludge sample, US EPA Method 3031for acid digestion of oils for metals was applied with little adjustment. A representative $5.0 \mathrm{~g}$ sample of the oily sludge was mixed with $3.0 \mathrm{~g}$ of finely ground potassium permanganate and then $2.0 \mathrm{~mL}$ of concentrated $\mathrm{H}_{2} \mathrm{SO}_{4}$ was added while stirring. A strong exothermic reaction occurs. The sample was then treated with $2 \mathrm{~mL}$ concentrated $\mathrm{HNO}_{3} .10 \mathrm{~mL}$ of concentrated $\mathrm{HCl}$ was added and the sample was heated until completion of reaction and then filtered. To remove the manganese, the digestate was neutralized with concentrated ammonium hydroxide. The sample was brought to volume. The extracts were analyzed for heavy metals $(\mathrm{Cr}, \mathrm{Cd}, \mathrm{Pb}, \mathrm{Ni}, \mathrm{As}, \mathrm{Cu}, \mathrm{Co}$, $\mathrm{Mn}, \mathrm{Fe}$ and $\mathrm{Zn}$ ) using atomic absorption spectrophotometer (AAS) iCE 3000 Series at their respective wavelength (357.9, $228.8,283.3,422.7,232.0,324.8,240.7,279.5,248.3$ and $213.9 \mathrm{~nm}$ ) according to APHA method [APHA, 2009]. $\mathrm{Hg}$ was analyzed by the flameless AAS using the cold vapour mode.

\section{Results and Discussion}

The numerous processes and facilities within the refinery, coupled with the procedure of handling as well as storage serve as avenues for release into the environment. In this study, the total petroleum hydrocarbon (TPH) and polyaromatic hydrocarbon $(\mathrm{PAH})$ concentrations in the sludge, soil and water were detected in each sample at $65,346.8(\mathrm{mg} / \mathrm{kg}), 4,190.6(\mathrm{mg} / \mathrm{kg})$ in the sludge, $8,756.1$ $(\mathrm{mg} / \mathrm{kg}), 311.6(\mathrm{mg} / \mathrm{kg})$ in the soil and $755.3(\mathrm{mg} / \mathrm{l}), 22.7$ $(\mathrm{mg} / \mathrm{l})$ for the water samples respectively (Table 1$)$.

Discharge from petrochemical industries, laced with a range of chemicals, trigger environmental and health concerns. Quantification of the soil, sludge and water surrounding the refinery in this study is an important physical factor in the determination of the toxicity levels which would otherwise contaminate the food chain by way of useful microorganisms, plants and marine organisms.

Table 1. Hydrocarbon concentration of samples.

\begin{tabular}{lll}
\hline Sample & Total Petroleum Hydrocarbon (TPH) & Total Polycyclic aromatic Hydrocarbon (TPAH) \\
\hline Water sample & $755.291(\mathrm{mg} / \mathrm{L})$ & $22.746(\mathrm{mg} / \mathrm{L})$ \\
Sludge sample & $65346.8(\mathrm{mg} / \mathrm{kg})$ & $4190.598(\mathrm{mg} / \mathrm{kg})$ \\
Soil sample & $8756.148(\mathrm{mg} / \mathrm{kg})$ & $311.569(\mathrm{mg} / \mathrm{kg})$ \\
\hline
\end{tabular}

The $\mathrm{pH}$ of the environment is important as different vegetable and microbial life forms blossom at varying $\mathrm{pH}$ levels, usually tending to neutral [28]. It was, therefore, very important to determine soil $\mathrm{pH}$ in this study. Data obtained showed that the $\mathrm{pH}$ of the studied samples were 5.2, 5.3 and 5.3 for the soil, sludge and water respectively (Table 2). The 
$\mathrm{pH}$ range of oil contaminated environments general tends to be acidic with a reduced level of porosity as against the norm of 6.7 [29]. Run-offs from the refinery would account for the increased in $\mathrm{pH}$ observed in the sludge samples as the source of the concentrated pollutants whereby via the natural process of leaching, these contaminants leach out into the waterways resulting in the increased $\mathrm{pH}$ of the water samples.

This as well could dissipate the fundamental salts in the sludge and water samples with active movement in the soil as the zone in between the point of origin and its final destination; the water ways.

As a physicochemical parameter, $\mathrm{pH}$ regulates the ion solubility and availability, thereby influencing plant and microbial activities and dispersion of nutrients [21].

Furthermore, the $\mathrm{pH}$ level is a good indicator of the polluting elements end-point, leachability and decomposition which in effect affects the physical, chemical and biological properties of the environment [28].

Table 2. Physicochemical parameters of oily samples.

\begin{tabular}{llll}
\hline Parameter & Sludge & Soil & Water \\
\hline $\mathrm{pH}$ & 5.3 & 5.2 & 5.3 \\
Conductivity $(\mu \mathrm{s} / \mathrm{cm})$ & 0.27 & 0.25 & 0.48 \\
Temperature $\left({ }^{\circ} \mathrm{C}\right)$ & - & - & 29.6 \\
Moisture content $(\%)$ & 3.70 & 1.00 & 145 \\
Total hardness $(\mathrm{mg} / \mathrm{l})$ & - & - & - \\
Organic matter $(\%)$ & 7.83 & 8.27 & 1576 \\
TDS $(\mathrm{mg} / \mathrm{l})$ & - & - & 0.65 \\
Total alkalinity $(\mathrm{mg} / \mathrm{l})$ & 0.82 & 1.05 & 1479 \\
TSS $(\mathrm{mg} / \mathrm{l})$ & - & - & 24.81 \\
Sulphate $(\mathrm{mg} / \mathrm{l})$ & 10.59 & 12.73 & 1.83 \\
DO $(\mathrm{mg} / \mathrm{l})$ & - & - & 194 \\
BOD $(\mathrm{mg} / \mathrm{l})$ & - & - & 288 \\
Chloride $(\mathrm{mg} / \mathrm{l})$ & 319 & 295 & 975 \\
Oil and grease $(\mathrm{mg} / \mathrm{l})$ & 15756 & 15628 & \\
\hline
\end{tabular}

The lower moisture content observed in the soil samples compared to that of the sludge is attributed to the presence of total petroleum and polycyclic aromatic hydrocarbons, which a study has reported causes an increase in soil hydrophobicity which would lead to a reduced moisture holding capacity [30]. Such contaminants trigger the release of carbon dioxide from the soil which in time would later affect the $\mathrm{pH}$.

The presence of petroleum contaminants in environmental samples affects the concentration of ions via the availability of dissolved solutes. Electrical conductivity was significantly higher in the water samples thus confirming the absence of petroleum products or the presence of a much reduced concentration of contaminated oil and hydrocarbon byproducts in the water samples (Table 2). Other researchers discovered that the dissolution of minerals particularly via natural degradation caused an increase in $\mathrm{pH}$, electrical conductivity and total dissolved solids in water and soil samples [31. Other factors considered to be directly impacting on the electrical conductivity of the environmental samples in this study would be the absence of oxygen, the presence of electron acceptors like nitrate ions and any possible dehydrogenation events taking place [21]. The lower levels of alkalinity in the sludge and water samples suggests that the inorganic elements, the macronutrients, within each sample reduces upon exposure to the polluting oils [32].

Organic matter is a characteristic feature of that affects the bioavailability of nutrients in an environmental sample and is closely related to both biodiversity population as well as the moisture content whereby a higher moisture content support the growth and availability of microorganisms which in turn supports plant metabolism via plant transport systems [33]. Organic matter is expected to be higher in petroleum contaminated environments as has been reported Ayodele and Omotoso [34]. In this study, the values obtained in the sludge sample was high, $7.83 \%$ respectively which was within the reported range observed in another report [34]. The $8.27 \%$ organic matter content observed in the soil samples could be attributed to the presence of other organic additives like pesticides, fertilizers, in particular would be dead or decaying plant material. All natural water ways contain acceptable limits of dissolved solids and a mixture of suspended organic and inorganic substances [35]. The obtained value for the total dissolved solids (TDS) was 1576 $(\mathrm{mg} / \mathrm{L})$. Research show that electrical conductivity and total dissolved solids and soluble solids (TSS) share a linear relationship whereby the higher the electrical conductivity, the higher the TDS and total soluble solutes [36].

Enumeration of the bacterial population of the studied samples (Table 3) revealed that the soil sample possessed a higher quantity of microorganism per gram $\left(7.29 \times 10^{3} \mathrm{cfu} / \mathrm{g}\right)$ in comparison to that of the sludge $\left(1.84 \times 10^{3} \mathrm{cfu} / \mathrm{g}\right)$ whereas that of the water sample was $1.32 \times 10^{3}(\mathrm{cfu} / \mathrm{ml})$. A higher concentration of microorganisms in the soil was expected as such are organism are ubiquitous in nature, existing in all habitat types.

Table 3. Bacteriological analysis results.

\begin{tabular}{ll}
\hline SAMPLE & TOTAL BACTERIAL COUNT $($ TBC) \\
\hline Water sample & $1.32 \times 10^{3}(\mathrm{cfu} / \mathrm{ml})$ \\
Sludge sample & $1.84 \times 10^{4}(\mathrm{cfu} / \mathrm{g})$ \\
Soil sample & $7.29 \times 10^{3}(\mathrm{cfu} / \mathrm{g})$ \\
\hline
\end{tabular}

The augmentation of soil microorganisms with that obtained from the sludge would undoubtedly increase the microbial number particularly if such microorganisms already possess a form of tolerance to certain limits of 
hydrocarbon bombardment. In this study, the enumerated bacterial numbers were not as high as other reported studies which suggests that the control limits for petroleum product within the soil had elapsed, thereby leading to a loss of viable organisms, as a result reducing their population [31], [37-40]. Other considerations include the cascading events triggered by the spill of excess hydrocarbons which increase the $\mathrm{pH}$ and causes a reduction in porosity as well as a disruption of gaseous exchanges via the retention of carbon dioxide, the presence of petroleum additives like heavy metals, etc, all of which lead to a reduction in the population of microorganisms in the contaminated environment [41]. Heavy metals are useful for biological growth and development but when they are introduced via leach or chemical reactions from storage tanks, petroleum pipelines, etc [42].

Table 4. Heavy metals concentrations of the samples.

\begin{tabular}{llll}
\hline Heavy metals & Soil $(\mathbf{m g} / \mathbf{k g})$ & Sludge $(\mathbf{m g} / \mathbf{k g})$ & Water $(\mathbf{m g} / \mathbf{l})$ \\
\hline Chromium & 0.640 & 24.250 & 0.129 \\
Cadmium & 0.090 & 0.038 & 0.139 \\
Lead & 1.052 & 3.902 & 0.234 \\
Mercury & 0.136 & 0.210 & 0.032 \\
Nickel & 0.278 & 0.459 & 0.606 \\
Arsenic & 0.215 & 0.417 & 0.098 \\
Copper & 0.263 & 2.015 & 0.201 \\
Cobalt & - & 0.275 & 0.340 \\
Manganese & 10.082 & 82.695 & 31.467 \\
Iron & 108.771 & 94.721 & 47.304 \\
Zinc & 11.072 & 9.909 & 8.209 \\
\hline
\end{tabular}

Data obtained in this current study (Table 4) revealed that with the exception of nickel, iron and zinc, the sludge samples contained the highest concentrations of chromium (24.25 mg/kg), lead (3.902 mg/kg), mercury $(0.21 \mathrm{mg} / \mathrm{kg})$, arsenic $(0.417 \mathrm{mg} / \mathrm{kg})$, copper $(2.015 \mathrm{mg} / \mathrm{kg})$ and manganese $(82.695 \mathrm{mg} / \mathrm{kg})$. These elements were expected to be detected in the sludge samples but in lower concentrations as part of industry awareness of their deleterious effects on the environment, thereby necessitating containment and treatment processes prior to release. In the immediate soil around the environment, iron $(108.77 \mathrm{mg} / \mathrm{kg})$ and zinc $(11.072 \mathrm{mg} / \mathrm{kg})$ where highest of all studied samples as these are already present in the soil, performing important metabolic functions to both vegetative and microbial life [42] The higher concentrations of various heavy metals in soil samples is attributed to their release from industrial effluents. The higher presence of cadmium $(0.139 \mathrm{mg} / \mathrm{l})$, cobalt $(0.34$ $\mathrm{mg} / \mathrm{l})$ and nickel $(0.606 \mathrm{mg} / \mathrm{l})$ in the water samples are all above the permissible world health organization (WHO) limits for ground water [43]. Effluents from the petrochemical industrial activities would account for this and also serves as a measure to determine whether the treatment or containment facilities in place require an upgrade.

\section{Conclusion}

Data obtained in this study has shown that higher concentrations of TPH and TPAH were obtained from the sludge $(65,326.8$ and $4,190.598 \mathrm{mg} / \mathrm{kg})$ than that of the soil $(8,756.148$ and $311.569 \mathrm{mg} / \mathrm{kg})$. The presence of these hydrocarbons contributed to the measured differences in the physicochemical characteristics of the samples which leaches into the waterways $(755.291$ and $22.746 \mathrm{mg} / \mathrm{L})$ via the soil where it accumulates and enters the food chain (Table 1). This study showed that the elevated concentrations of petroleum products and heavy metals, accumulate in the soil and water which affects their physicochemical properties, including microbial life (Table 2-4). The presence of these mixed concentration of pollutants causes an increase in soil $\mathrm{pH}$, leaning towards acidic (5.2-5.3) in the soil, sludge and water samples in addition to a reduction in porosity, increased carbon dioxide presence and an increase in electrical conductivity all of which reduces the availability of essential nutrients in each environmental sample. The results of the study could be utilized as a baseline towards the development and implementation of both remediation and in situ containment techniques.

\section{Acknowledgements}

The authors would like to thank Mr. Godwin Etuk-Udo of the Biotechnology Advanced Research Centre, Sheda Science and Technology Complex (SHESTCO) for useful technical discussions.

\section{References}

[1] Hentati O., Lachhab R., Ayadi M., and Ksibi M., (2013). Toxicity assessment for petroleum-contaminated soil using terrestrial invertebrates and plant bioassays. Environmental Monitoring and Assessment, 185: 2989-2998.

[2] Bierkens J., and Geerts L., (2014). Environmental hazard and risk characterization of petroleum substances: a guided "walking tour" of petroleum hydrocarbons. Environmental International, 66: 182-193.

[3] Olajire A. A., Altenburger R., Küster E., and Brack W., (2005). Chemical and eco-toxicological assessment of polycyclic aromatic hydrocarbon-contaminated sediments of the Niger Delta, Southern Nigeria. Science of the Total Environment, 340: 123-136. 
[4] Sojinu O. S. S., Wang J. Z., Sonibare O. O., and Zeng E. Y., (2010). Polycyclic aromatic hydrocarbons in sediments and soils from oil exploration areas of the Niger Delta, Nigeria. Journal of Hazardous Materials, 174: 641-647.

[5] Macci C., Doni S., Peruzzi E., Bardella S., Filippis G., Ceccanti B., and Masciandaro G., (2013). A real-scale soil phytoremediation. Biodegradation, 24: 521-538.

[6] Anyakora C., Ogbeche A., Palmer P., and Coker H., (2005). Determination of polynuclear aromatic hydrocarbons in marine samples of Siokolo Fishing Settlement. Journal of Chromatography A, 1073: 323-330.

[7] Ruffin S., (2012). Royal dutch shell environmentally degrades Nigeria's Niger Delta region: A land of blacks. Environmental Justice, 5: 140-152.

[8] Jesus J. M., Danko A. S., Fiúza A., and Borges M. T., (2015) Phytoremediation of salt-affected soils: a review of processes, applicability, and the impact of climate change. Environmental Science and Pollution Research, 22: 65116525.

[9] Obiajunwa E. I., Pelemo D. A., Owolabi S. A., Fasasi M. K., and Johnson-Fatokun F. O., (2002). Characterization of heavy metal pollutants of soils and sediments around a crude-oil production terminal using EDXRF. Nuclear Instruments and Methods in Physics Research, Section B: Beam Interactions with Materials and Atoms, 194: 61-64.

[10] Omokaro O., (2009). Oil and gas extraction in the Niger Delta region of Nigeria: The social and environmental challenges. FOG - Freiberg Online Geoscience, 24: 14-20.

[11] Gao Y., and Collins C. D., (2009). Uptake pathways of polycyclic aromatic hydrocarbons in white clover. Environmental Science and Technology, 43: 6190-6195.

[12] Cook R. L., Landmeyer J. E., Atkinson B., Messier J. P., and Nichols E. G., (2010). Field note: successful establishment of a phytoremediation system at a petroleum hydrocarbon contaminated shallow aquifer: trends, trials, and tribulations. International Journal of Phytoremediation, 12: 716-732.

[13] Fester T., Giebler J., Wick L. Y., Schlosser D., and Kästner M., (2014). Plant microbe interactions as drivers of ecosystem functions relevant for the biodegradation of organic contaminants. Current Opinions in Biotechnology, 27: 168175 .

[14] Gaskin S. E., and Bentham R. H., (2010). Rhizoremediation of hydrocarbon contaminated soil using Australian native grasses. Science of the Total Environment, 408: 3683-3688.

[15] Masakorala K., Yao J., Chandankere R., Liu H., Liu W., Cai M., and Choi M. F., (2014). A combined approach of physicochemical and biological Methods for the characterization of petroleum hydrocarbon contaminated soil. Environmental Science and Pollution Research, 21: 454-463.

[16] Roane T. M., Josephson K. L., and Pepper I. L., (2001). Dualbioaugmentation strategy to enhance remediation of cocontaminated soil. Applied Environmental Microbiology, 67: 3208-3215.

[17] Liu H., Probst A., and Liao B., (2005). Metal contamination of soils and crops affected by the Chenzhou lead/zinc mine spill (Hunan, China). Science of the Total Environment, 339: 153166.
[18] Anderson C., and Cook G. M., (2004). Isolation and characterization of arsenate-reducing bacteria from arsenic contaminated sites in New Zealand. Current Microbiology, 48: 341-347.

[19] Towell M. G., Bellarby J., Paton G. I., Coulon F., Pollard S. J. T., and Semple K. T., (2011). Mineralization of target hydrocarbons in three contaminated soils from former refinery facilities. Environmental Pollution, 159: 515-523.

[20] Haslmayr H. P., Meissner S., Langella F., Baumgarten A., and Geletneky J., (2014). Establishing best practice for microbially aided phytoremediation. Environmental Science and Pollution Research, 21: 6765-6774.

[21] Osuji L. C., and Nwoye I., (2007). An appraisal of the impact of petroleum hydrocarbons on soil fertility: the Owaza experience. African Journal of Agricultural Research, 2: 318 324.

[22] Ibitoye A. A., (2006). Laboratory Manual on Basic Soil Analysis. 2nd Edition, Foladave Nigeria Ltd., Akure, Nigeria, $70 \mathrm{pp}$.

[23] Maiti S. K., (2003). Handbook of Methods in Environmental studies. Vol. 2 Air, Noise, Soil and Overburden Analysis. Oxford Book Company, Jaipur, Rajasthan, India.

[24] APHA (American Public Health Association) (1998). Standard Methods for the Examinations of Water and Wastewater, $20^{\text {th }}$ edition, Washington DC.

[25] Ujowundu C. O., Kalu F. N., Nwaoguikpe R. N., Kalu O. I., Ihejirika C. E., Nwosunjoku E. C., and Okechukwu R. I., (2011). Biochemical and physical characterization of diesel petroleum contaminated soil in southeastern Nigeria. Research Journal of Chemical Science, 1: 57-62.

[26] Bennett B., Larger A., Potter D. K., Buckman J. O., and Larter S. R., (2007). Petroleum geochemical proxies for reservoir engineering parameters. Journal of Petroleum Science and Engineering, 58: 367-347.

[27] Wang Z., and Stout S A., (2016). Standard Handbook Oil Spill Environmental Forensics: Fingerprinting and Source Identification. Elsevier/Academic Press.

[28] Osuji L. C., and Adesiyan S. O., (2005). The Isiokpo oilpipeline leakage: total organic carbon/organic matter contents of affected soils. Chemistry and Biodiversity, 2: 1079-1085.

[29] Obire O., and Nwaubeta O., (2002). Effects of refined petroleum hydrocarbon on soil physicochemical and bacteriological characteristics. Journal of Applied Science and Environmental Management, 6: 39-44.

[30] Balks M. R., Paetzold R. P., Kimble J. M., Aislabie J., and Campbell I. B., (2002). Effects of hydrocarbon spills on the temperature and moisture regimes of Cryosols in the Ross Sea region. Antarctic Science, 14: 319-326.

[31] Allen J. P., Atekwana E. A., Duris J. W., Werkema D. D., and Rossbach S., (2007). The microbial community structure in petroleum-contaminated sediments corresponds to geophysical signatures. Applied Environmental Microbiology, 73: $2860-2870$.

[32] Hawrot M., and Nowak A., (2006). Effects of different soil treatments on diesel fuel biodegradation. Polish Journal of Environmental Studies, 15: 643-646. 
[33] Chaudhary P., Singh S. B., Chaudhry S., and Nain L., (2012). Impact of PAH on biological health parameters of soils of an Indian refinery and adjoining agricultural area- A case study. Environmental Monitoring and Assessment, 184: 1145-1156.

[34] Ayodele O. J., and Omotoso S. O., (2008). Nutrient management for maize production in soils of the savannah zone of south-western Nigeria. International Journal of Soil Science, 3: 20-27.

[35] Ajarmeh H., Al-Hassan A., and Wegelin M., (2007). SODIS: An emerging water treatment process. Aqua (Oxford), 46: 127-137.

[36] Neol H. T., (2009). Focus on Africa, a critical need. Network for Cost-Effective Technologies in Water Supply and Sanitation, St. Gallien, Switzerland. 15-19.

[37] Ueno A., Ito Y., Yamamoto Y., Yumoto I., Okuyama H., (2006). Bacterial community changes in diesel-oilcontaminated soil microcosms bio-stimulated with LuriaBertani medium or bioaugmented with a petroleum-degrading bacterium Pseudomonas aeruginosa strain Wat G. Journal of Basic Microbiology, 46: 310-317.

[38] Salehi R., Shayegan J., Ghavipanjeh F., Pazouki M., Hosseinnia A., (2009). Anaerobic Bioconversion of Heavy Hydrocarbons Using Native Consortia. Iranian Journal of Chemical Engineering, 6: 40-49.
[39] Fariba M., Abdolkarim C. R., and Mehrangiz A., (2012). Evaluation of oil removal efficiency and enzymatic activity in some fungal strains for bioremediation of petroleum-polluted soils. Iranian Journal of Environmental Health Sciences \& Engineering, 9: 26-34.

[40] Shumin Y., Na N., Zhaoyanga X., Jinglia T., (2012). Screening and identification of halotolerant yeast for hydrocarbon degrading and its properties studies. African Journal of Microbiology Research, 6: 1819-1828.

[41] Luepromchai E., Lertthamrongsak W., Pinphanichakarn P., Thaniyavarn S. P., and Juntogjin K., (2007). Biodegradation of PAHs in petroleum contaminated soil using tamarind leaves as microbial inoculums. Journal of Science and Technology, 29: $515-527$.

[42] Mahamuda K., Bera P., Mitra D., Mandal A., and Samanta A., (2012). Estimation of heavy metal tolerance and antibiotic susceptibility of Bacillus cereus isolated from municipal solid waste. International Journal of Pharmaceutical and Biological Science, 3: 819-829.

[43] Oyeku O. T., and Eludoyin A. O., (2010). Heavy metal contamination of groundwater resources in a Nigerian urban settlement. African Journal of Environmental Science and Technology, 4: 201-214. 